\title{
GAP ANALYSIS AND STRATEGY OF PT. TRANSPORTASI JAKARTA IN IMPROVING ITS SERVICES PERFORMANCE
}

\author{
Wisnu Surianugraha*), Yusman Syaukat ${ }^{* *}$, and Dwi Rachmina ${ }^{* * *}$ \\ *) The Management of Regional Development Study Program, Graduate School, IPB University \\ Jl. Raya Darmaga, Darmaga Campus, IPB Graduate School Building, Bogor 16680, Indonesia \\ ${ }^{* *}$ Department of Resources and Environmental Economics, Faculty of Economics and Management, IPB University \\ Jl. Agatis, IPB Darmaga Campus, Bogor 16680, Indonesia \\ **) Department of Agribusiness, Faculty of Economics and Management, IPB University \\ Jl. Agatis, IPB Darmaga Campus, Bogor 16680, Indonesia
}

\begin{abstract}
PT. Transportasi Jakarta runs the Transjakarta services based on the standards that had been regulated as one of the variables for the financial support which is given from the Regional Government. As stated in the Governor Regulation Number 62 of 2016 and Governor Regulation Number 33 of 2017, the Regional Government needs to evaluate the performances of the company to fulfill the service standards considering the implementations of fines that will be applied if the standards did not achieve, thus the financial support will be ineffective and inefficient. The purpose of this study is to analyze the performance of PT. Transportasi Jakarta in attaining its Minimum Services Standards, and to develop the strategies to improve its service performance. The study uses Gap Analysis with secondary data from the Evaluation Report of Transjakarta Services in the Fourth quarter of 2018, and Analytical Hierarchy Process with primary data from the questionnaire given to respondents from all the related stakeholders. The result of this study shows that the performance of PT. Transportasi Jakarta has not yet reached the Minimum Service Standards. To improve the performance, the basic safety service needs to be prioritized by implementing a human resource development program. This could include open recruitment, capacity building, key performance indicators, and remuneration system. The renewal, mobilization of Transjakarta fleets, and integrated control system become the next strategy to improve punctuality since this type of service had the biggest fines applied and as the core service of Transjakarta services in providing mass transportations.
\end{abstract}

Keywords: transjakarta, minimum service standard, gap analysis, analytical hierarchy process

\begin{abstract}
Abstrak: PT. Transportasi Jakarta menyelenggarakan pelayanan Transjakarta berdasarkan standar pelayanan yang telah ditetapkan sebagai dasar atas pemberian dukungan pendanaan Pemerintah Daerah. Sebagaimana Peraturan Gubernur Nomor 62 Tahun 2016 dan Peraturan Gubernur Nomor 33 Tahun 2017, Pemerintah Daerah perlu memperhatikan kinerja badan usaha atas standar pelayanan dimana apabila tidak tercapai maka terdapat denda-denda yang diberikan atas hal tersebut, sehingga pemberian dukungan pendanaan Pemerintah menjadi tidak efektif dan efisien. Tujuan penelitian adalah untuk melakukan evaluasi atas kinerja PT. Transportasi Jakarta terhadap Standar Pelayanan Minimal Transjakarta yang telah ditetapkan pada Triwulan IV Tahun 2018 dan merumuskan strategi peningkatan kinerja. Dalam memenuhi tujuan tersebut, kajian penelitian menggunakan metode GAP Analysis melalui data sekunder berupa Laporan Evaluasi Triwulan IV Survey Capaian SPM Transjakarta 2018, dan Analytical Hierarchy Process (AHP) melalui data primer berupa kuesioner dengan para responden. Hasil kajian memperlihatkan bahwa kinerja PT. Transportasi Jakarta belum memenuhi Standar Pelayanan. Dalam melakukan peningkatan kinerja, jenis pelayanan dasar Keselamatan menjadi prioritas melalui strategi pengembangan kompetensi sumber daya open recruitment, capacity building, key performance indicators, dan pemberian remunerasi. Pemilihan strategi peremajaan, mobilisasi armada dan sistem kontrol yang terintegrasi menjadi prioritas strategi berikutnya untuk meningkatkan kinerja pad ajenis pelayanan dasar Keteraturan sehingga denda terbesar yang diterima dalam pelayanan tersebut dapat ditekan.
\end{abstract}

Kata kunci: transjakarta, standar pelayanan minimum, gap analysis, analytical hierarchy process

\footnotetext{
${ }^{1}$ Corresponding author:

Email: wisnusuria@gmail.com
} 


\section{INTRODUCTION}

The Jakarta Provincial Government came up with the idea to establish a bus rapid transit system that aims to revive the operation of mass public transport with professional service standards. This concept as a solution to unravel congestion by reducing the number of private vehicle usage. The first Transjakarta served the Blok M corridor to the Kota in 2004. On the year of 2017, the number of operating fleets has reached 1347 units and served 13 corridors. Finally, In 2014, The Jakarta Provincial Government has formed a Regional Owned Enterprise named PT. Transportasi Jakarta with the Regional Regulation Number 4 the Year 2014.

PT. Transportasi Jakarta runs the Transjakarta busway services based on the Minimum Service Standards that have been set as guidelines for service quality and for evaluating the performance of business entities towards the financial support of Public Service Obligations from the Government. The Performance of PT. Transportasi Jakarta has an impact on Transjakarta services in general and becomes one of the influencing variables of the financial support because, with the non-fulfillment of the service standards, there will be various types of fines that apply so that the utilization of financial support become ineffective and inefficient.

Kamaludin (2003) stated in general views, the transportation sector is very vital both from an economic and social standpoint, thus the transportation sector needs attention and assistance from the government. In providing financial support as mandated by the Governor Regulation Number 62 the Year 2016, and the Governor Regulation Number 33 the Year 2017, PT Transjakarta is required to fulfill the Minimum Service Standards indicators that have been set in the operation of Transjakarta service.
Transjakarta is one of the programs from the Jakarta Provincial Government to develop road-based public transportation and also become a pioneer of public transportation reform that prioritizes comfort, security, safety, and affordability for the people of Jakarta Capital City. But, until now there are still factors causing the dissatisfaction of Transjakarta users, which indicates that the Transjakarta management still needs to be well managed (Ismiyati et al. 2016).

Referring to Table 1, it can be seen that the average of services standards for 6 basic services is 97,70 percent, while the performance of PT. Transportasi Jakarta is 90,09 percent, which means that it is still 7.61 percent below standard. The consequences of the failure to achieve the service standards are causing to subject a fine of Rp1.3 billion in 2017 for PT. Transportasi Jakarta (Dishub, 2017). Haryoto (2013) argues that as a government policy in the administration of public transportation the budget must be related to the service that has been given.

Transjakarta has the vision to be the best service provider company in the field of transportation, while its mission is to provide satisfaction to the community with excellent and innovative services (Arifin et al. 2015). The role of PT. Jakarta's transportation in carrying out service performance to the community has become a significant form of contribution in reducing the level of congestion. This is indicated by a large number of users with an increasing trend every year. Table 2 shows that the number of users of Transjakarta services in 2012 to 2017 reached an average of over 100 million users per year.

Table 1. PT. Transportasi Jakarta Level of Performance in 2017

\begin{tabular}{lccccc}
\hline Basic Service & Indicators & Standard (\%) & Performance $(\%)$ & Differences (\%) & Fines (Rp) \\
\hline Security & 9 & 98.89 & 96.38 & 2.51 & $98,457,251$ \\
Safety & 9 & 100 & 81.46 & 18.54 & $540,514,863$ \\
Convenience & 8 & 95 & 86.81 & 8.19 & $340,604,635$ \\
Affordability & 1 & 95 & 100.00 & $(5.00)$ & - \\
Equality & 2 & 100 & 98.20 & 1.80 & $23,348,094$ \\
Punctuality & 8 & 96.25 & 92.75 & 3.50 & $304,853,541$ \\
\hline & 37 & 97.70 & 90.09 & 7.61 & $1,307,778,834$ \\
\hline
\end{tabular}


Table 2. The amount of Transjakarta Passengers in $2012-2017$

\begin{tabular}{cc}
\hline Year & Passengers \\
\hline 2012 & $114,769,311$ \\
2013 & $111,260,869$ \\
2014 & $112,522,638$ \\
2015 & $102,950,384$ \\
2016 & $123,706,856$ \\
2017 & $144,868,949$ \\
\hline
\end{tabular}

However, the existence of Transjakarta has not been able to make people feel comfortable, the mode of transportation has only succeeded in diverting about 22.5 percent of personal vehicle users (Gultom, 2014). In continuing to perform Transjakarta services in overcoming the congestion problems and in order to maintain the quality of service for the average number of 100 million per year, PT. Transportasi Jakarta needs to work towards the service standards as specified. In addition to external factors in the form of support provided by the Jakarta Provincial Government, PT. Transportasi Jakarta as a Regional Owned Enterprise needs to improve the company's performance independently. This paper aims to analyze the performance of PT. Transportasi Jakarta in achieving the minimum service standards, as well as formulating strategies in improving company capability.

\section{METHODS}

This research start from the implementation of Transjakarta services that influenced by two main variables, which are the plan of minimum service standard targets and the provision of government funding support. These two variables greatly affect each other on the performance of PT. Transportasi Jakarta. With the service performance that being able to meet the minimum service standards in addition to maintain and improve the service quality, it will also have an impact on the provision of fines or penalties for the funding support so that it becomes ineffective and inefficient. Furthermore, in order to analyze the performance of PT. Transportasi Jakarta, the study uses a comparative analysis method. While in finding priority of strategies and policy programs, a method of analysis through a quantitative hierarchical structure is needed.
The study was conducted in Jakarta Capital City Province, by involving the Transportation Agency (Dishub) and PT. Transportasi Jakarta. The study was carried out in the period of 4th quarter of 2018, started from August until November 2018. There are two types of data sources that had been used for this research, first by analyzing secondary data from the Transjakarta Service Standard Evaluation Report in 2018, and second by conducting primary data collection through in-depth interviews and questionnaires from the related respondents such as the Regional Development Planning Agency (Bappeda), the Transportation Agency (Dishub), and PT. Transportasi Jakarta.

Furthermore, this study uses two data analysis techniques which are Gap Analysis and Analytical Hierarchy Process (AHP). The services standards achievement of Transjakarta was analyzed using the Gap Analysis method with the following steps: 1) identification of the 6 basic service types with 37 indicators; 2) determine the evaluation period, in the 4th quarter of $2018 ; 3$ ) analyze the target plan in the Governor regulation Number 33 Year 2017; 4) analyze the Transjakarta Services Standards Evaluation Report; 5)descriptive data analysis; 6)follow-up. Research framework in Figure 1.

Analytical Hierarchy Process (AHP) was used in formulating strategies to improve company performance. Falatehan (2016) explains the earliest step in the AHP method is to break down the problem into its components, then arrange it in the form of a hierarchy. The preparation of the hierarchical structure starts from general objectives, criteria that affect the performance of PT. Transportasi Jakarta Minimum Service Standards, relevant actors, constraints, and desired policies based on observations and questionnaires conducted by respondents. The AHP model of PT. Transportasi Jakarta Minimum Service Standards and policy programs can be seen in Figure 2.

\section{RESULTS}

The performance of Transjakarta services are established by the Minimum Service Standards (Putra and Tangkudung, 2018), based on the results of Gap Analysis, it can be seen that the overall of the 6 basic types of services has not yet reached the Transjakarta Minimum Service Standards. In particular, the highest 
performance is on the basic types of Affordability and Equality with 99.92 percent of each, followed by the performance on the type of basic service Security with 98.94 percent, Convenience with 96.04 percent, Punctuality with 93.72 percent (Figure 3). The lowest achievement was in the type of basic service Safety with 92.68 percent. Fitriana et al. (2020), the non-fulfillment of service standards indirectly affects the nominal obtained by PT. Transportasi Jakarta. The Impact on the non-fulfillment of the Transjakarta Minimum Service Standards in Quarter IV 2018 are the applied fines of Rp1.3 billion, with the largest in the types of
Punctuality (Rp747 million), Safety (Rp420 Million), and Convenience (Rp262 million).

Based on the results of the Gap Analysis, it can also be seen that the performance of PT. Transportasi Jakarta in 2018 generally increases when compared to 2017. The performance of PT. Transportasi Jakarta in 2017 is 90.09 percent while in 2018 are 96.87 percent, so it increased by 6.78 percent. The performance of the five basic types of services increased when compared to 2017, while the performance of Affordability decreased (Table 3).

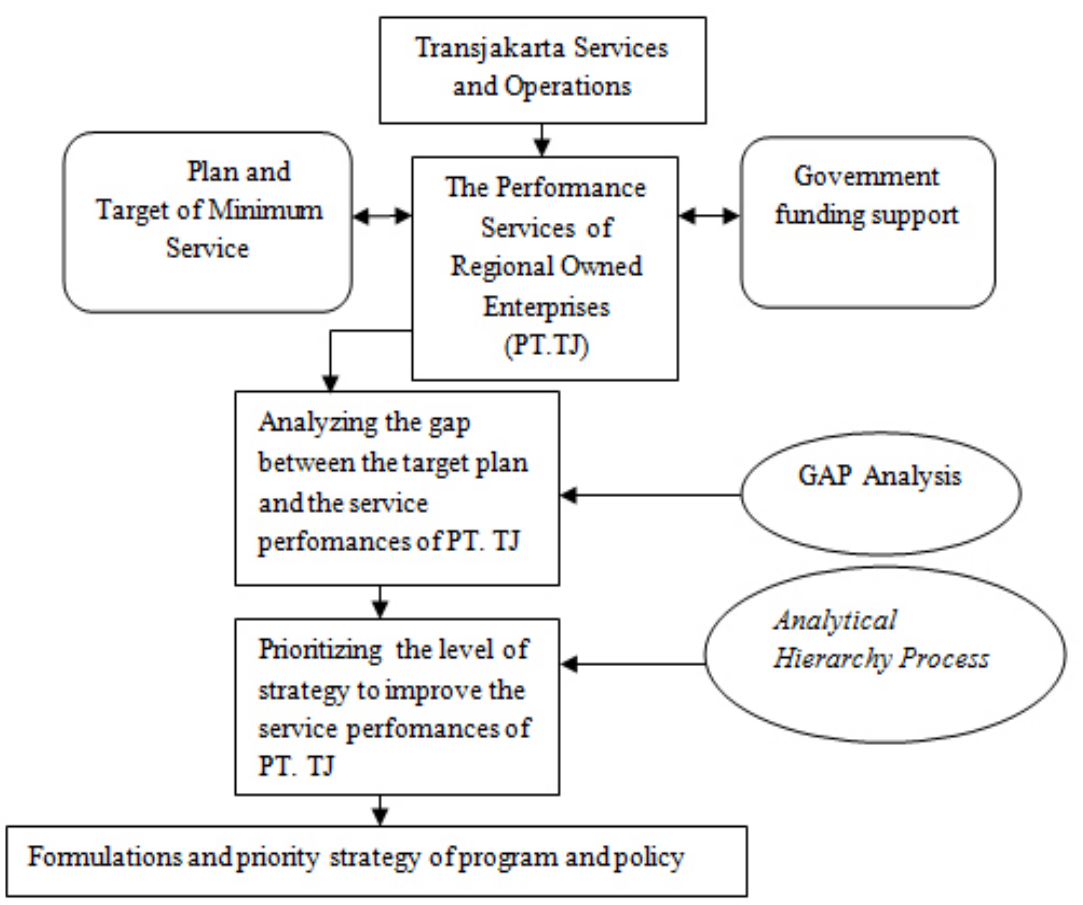

Figure 1. Research framework

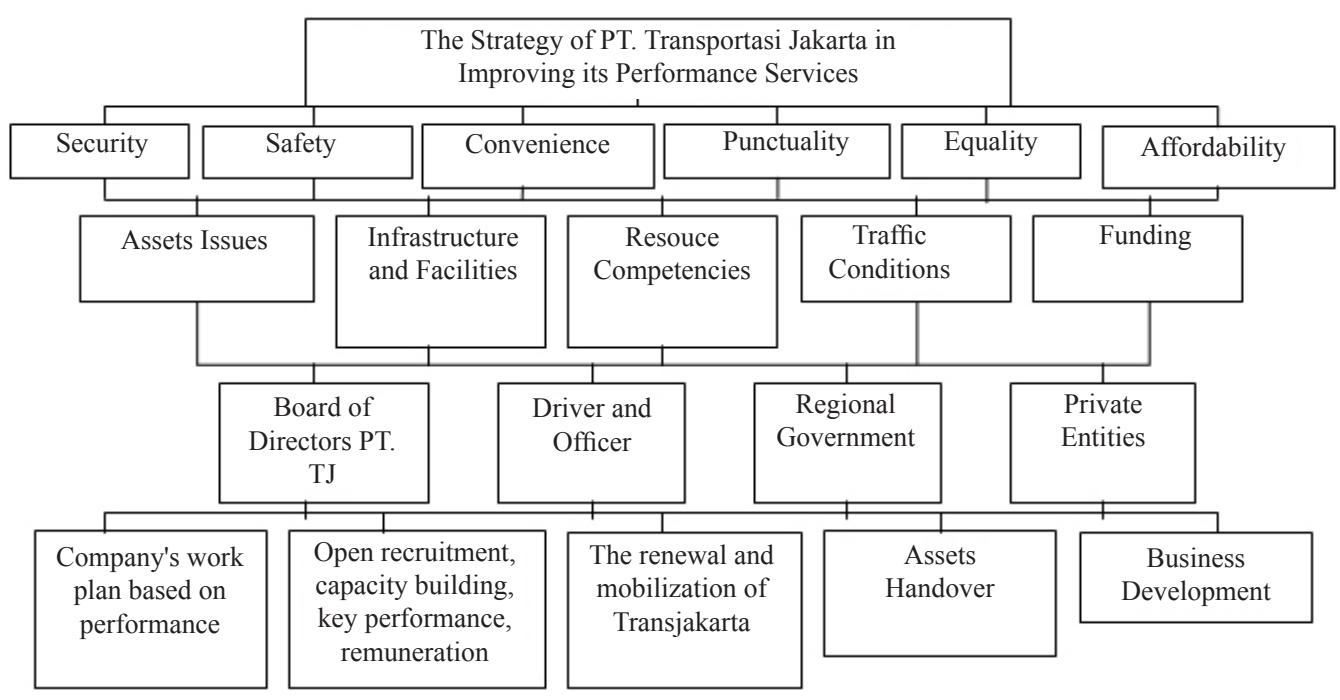

Figure 2. The Analytical Hierarchy Process (AHP) model 
AHP analysis is performed by using Expert Choice. Horizontal Analysis shows that the types of basic services that are prioritized for performance improvement are the basic types of safety services with a score of 0.278 . This is influenced by the variable competency of resources owned by PT. Transportasi Jakarta in operating procedures and handling emergencies. The next basic service types are Convenience with a score of 0.228 , Security with a score of 0.219 , and Punctuality with a score of 0.170 , while Affordability and Equality each have scores of 0.060 and 0.045 . The results of priority from the horizontal analysis of basic services in Table 4.

The next is the horizontal analysis result of an obstacle in fulfilling the 6 basic types of services. The priority on the basic types of services Security and Safety are competency resources owned by PT. Transportasi Jakarta with scores of 0.400 and 0.388 . Based on the results of the horizontal analysis, the priority on the basic types of services Convenience, Affordability, and Punctuality in traffic congestion constraints with scores of $0.419,0.317$, and 0.571 . Traffic congestion has the highest value, which means that congestion that occurs around the Transjakarta corridor has a significant impact on community activities in using the Transjakarta services. The punctuality of time which affects the community activities is not fulfilled, where the time of Transjakarta arrival is influenced by the waiting time required by the user (Danurekso et al. 2018). Priority on the basic types of Equality services is the completeness of infrastructure. The results of priority from the horizontal analysis of constraints in Table 5.

Furthermore, the priority results from the horizontal analysis between actors with the obstacles show that the actors holding the policies and implementing the Transjakarta program related to the assets issues are the Regional Government with a score of 0.550 . Then, the next one is PT. Transportasi Jakarta $(0.260)$, officers and drivers (0.097), and investors/private sector (0.093). The Regional Government gets the highest score because to increase Transjakarta services through asset optimization is highly depends on the policies taken by the Jakarta Provincial Government.

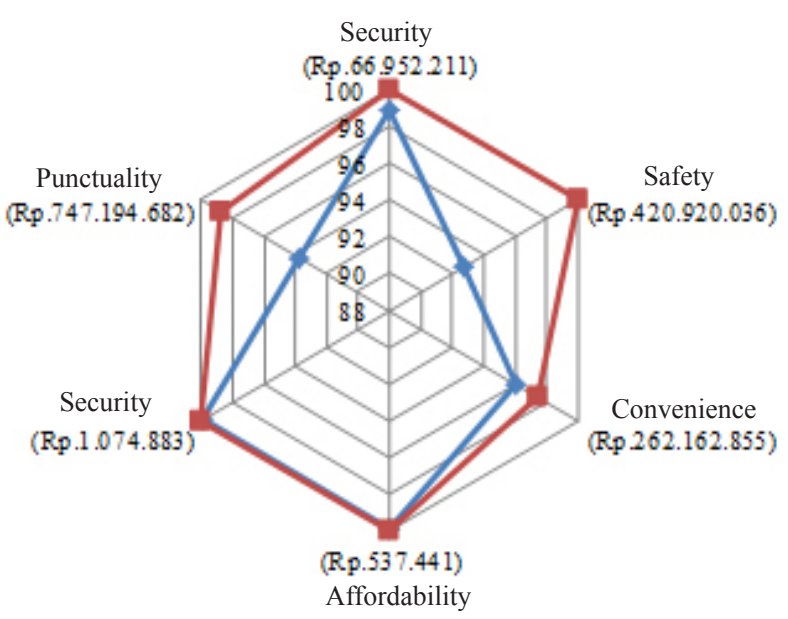

Figure 3. The performance and fines applied to PT. Tranportasi Jakarta in 2018

Table 3. The comparative performance of PT. Transportasi Jakarta in 2017 and 2018

\begin{tabular}{lccc}
\hline Basic Service & Performance in 2017 (percent) & Performance in 2018 (percent) & \\
\hline Security & 96.38 & 98.94 & Increased 2.56 percent \\
Safety & 81.46 & 92.68 & Increased 11.22 percent \\
Convenience & 86.81 & 96.04 & Increased 9.23 percent \\
Affordability & 100 & 99.92 & Decreased 0.08 percent \\
Equality & 98.20 & 99.92 & Increased 1.72 percent \\
Punctuality & 92.75 & 93.72 & Increased 0.97 percent \\
Average & 90.09 & 96.87 & Increased 6.78 percent \\
\hline
\end{tabular}


Table 4. The results of priority from the horizontal analysis of basic services

\begin{tabular}{llc}
\hline Basic Service & Score & Priority \\
\hline Safety & 0.278 & 1 \\
Convenience & 0.228 & 2 \\
Security & 0.219 & 3 \\
Punctuality & 0.170 & 4 \\
Affordability & 0.060 & 5 \\
Equality & 0.045 & 6 \\
\hline
\end{tabular}

Table 5. The results of priority from the horizontal analysis of constraints

\begin{tabular}{|c|c|c|c|}
\hline Basic Service & Constraints & Score & Priority \\
\hline \multirow[t]{5}{*}{ Security } & Resources Competencies & 0.400 & 1 \\
\hline & Infrastructure and Facilities & 0.286 & 2 \\
\hline & Funding Resources & 0.136 & 3 \\
\hline & Traffic Congestion & 0.118 & 4 \\
\hline & Assets Issues & 0.059 & 5 \\
\hline \multirow[t]{5}{*}{ Safety } & Resources Competencies & 0.388 & 1 \\
\hline & Infrastructure and Facilities & 0.299 & 2 \\
\hline & Funding Resources & 0.132 & 3 \\
\hline & Traffic Congestion & 0.116 & 4 \\
\hline & Asset Issues & 0.065 & 5 \\
\hline \multirow[t]{5}{*}{ Convenience } & Traffic Congestion & 0.419 & 1 \\
\hline & Infrastructure and Facilities & 0.262 & 2 \\
\hline & Resources Competencies & 0.185 & 3 \\
\hline & Funding Resources & 0.075 & 4 \\
\hline & Assets Issues & 0.058 & 5 \\
\hline \multirow[t]{5}{*}{ Affordability } & Traffic Congestion & 0.377 & 1 \\
\hline & Infrastructure and Facilities & 0.294 & 2 \\
\hline & Funding Resources & 0.202 & 3 \\
\hline & Resources Competencies & 0.069 & 4 \\
\hline & Assets Issues & 0.058 & 5 \\
\hline \multirow[t]{5}{*}{ Equality } & Infrastructure and Facilities & 0.532 & 1 \\
\hline & Funding Resources & 0.221 & 2 \\
\hline & Assets Issues & 0.089 & 3 \\
\hline & Resources Competencies & 0.083 & 4 \\
\hline & Traffic Congestion & 0.076 & 5 \\
\hline \multirow[t]{5}{*}{ Punctuality } & Traffic Congestion & 0.571 & 1 \\
\hline & Funding Resources & 0.138 & 2 \\
\hline & Infrastructure and Facilities & 0.122 & 3 \\
\hline & Resources Competencies & 0.109 & 4 \\
\hline & Assets Issues & 0.060 & 5 \\
\hline
\end{tabular}


Regional Government and the Board of Directors of PT. Transportasi Jakarta has the same score $(0.411)$ of the constraints in the completeness of infrastructure and facilities. The two actors have the highest value, meaning that during the process of handing over the infrastructure assets, the Jakarta Provincial Government needs to provide financial support while PT. Transportasi Jakarta as the operator needs to invest in providing Transjakarta fleet facilities.

Board of Directors of PT. Transportasi Jakarta along with the ranks of officers and drivers have scores of 0.464 and 0.387 for the resource competencies. This is because of the ability and competence of PT. Transportasi Jakarta resources in carrying out basic service indicators on Minimum Service Standards, such as vehicle operating procedures and emergency handling procedures are not the same and/or evenly equal.

Actors with traffic congestion constraints are the Regional Government with a score of 0.456 , then PT. Transportasi Jakarta (0.320), officers and drivers (0.158), and investors/private sector (0.066). Traffic congestion is an external obstacle to the performance of PT. Transportasi Jakarta in fulfilling the Transjakarta Minimum Services Standards, therefore the Government policy support in the form of engineering programs and traffic restrictions are needed, especially in fulfilling the types of basic services Convenience and Punctuality related to the time indicators. The results of priority from the horizontal analysis of actors in Table 6.

Actors from the constraints of funding are the investor/ private party with a score of 0.554 Government (0.206), and PT. Transportasi Jakarta (0.196). These things happened because of Transjakarta services, PT. Transportasi Jakarta received financial support from the Government. This condition can burden the fiscal capacity of the Regional Government. Ismiyati et al. (2016) stated that the implementation of the busway policy in Jakarta must be supported by sufficient financial resources. Financial resources are the main resources that need to be prepared, considering that infrastructure development and procurement require large funds. Therefore, the existence and the role of investors / private sector in Transjakarta is an alternative that can be elaborated together.

Table 6 . The results of priority from the horizontal analysis of actors

\begin{tabular}{|c|c|c|c|}
\hline Constraints & Actors & Score & Priority \\
\hline \multirow[t]{4}{*}{ Assets Issues } & Regional/ Local Government & 0.550 & 1 \\
\hline & Board of Directors PT. TJ & 0.260 & 2 \\
\hline & Drivers and Officers & 0.097 & 3 \\
\hline & Investor/ Private Sector & 0.093 & 4 \\
\hline \multirow[t]{4}{*}{ Infrastructure and Facilities } & Regional/ Local Government & 0.411 & 1 \\
\hline & Board of Directors PT. TJ & 0.411 & 1 \\
\hline & Drivers and Officers & 0.110 & 2 \\
\hline & Investor/ Private Sector & 0.067 & 3 \\
\hline \multirow[t]{4}{*}{ Resources Competencies } & Board of Directors PT. TJ & 0.464 & 1 \\
\hline & Drivers and Officers & 0.387 & 2 \\
\hline & Regional/ Local Government & 0.081 & 3 \\
\hline & Investor/ Private Sector & 0.067 & 4 \\
\hline \multirow[t]{4}{*}{ Traffic Congestions } & Regional/ Local Government & 0.456 & 1 \\
\hline & Board of Directors PT. TJ & 0.320 & 2 \\
\hline & Drivers and Officers & 0.158 & 3 \\
\hline & Investor/ Private Sector & 0.066 & 4 \\
\hline \multirow[t]{4}{*}{ Funding Resources } & Investor/ Private Sector & 0.554 & 1 \\
\hline & Regional/ Local Government & 0.206 & 2 \\
\hline & Board of Directors PT. TJ & 0.196 & 3 \\
\hline & Drivers and Officers & 0.044 & 4 \\
\hline
\end{tabular}


Horizontal analysis results for alternative and priority strategies for increasing PT. Transportasi Jakarta on the achievement of Minimum Services Standards to the Regional Government is the implementations of open recruitment, capacity building, key performance indicators, and remunerations, which score of 0.495 . This means that the Jakarta Provincial Government as the majority shareholder needs to encourage Regional Owned Enterprise to implement this matter through the work and budget plan mechanism. Next, followed by the performance-based work plan (0.186), business development (0.114), acceleration of the asset handover (0.107), and the renewal, mobilization, and integrated control systems (0.098).

The implementation of open recruitment, capacity building, key performance indicators, and remuneration is also a priority for PT. Transportasi Jakarta with a score of 0.420 . This strategy is a company's internal performance that needs to be prioritized because it is related to the competency of its resources. Transjakarta must improve service quality and provide the professionalism that places the values of safety, passenger comfort, and fulfill Minimum Service Standards as the main convenience of the Transjakarta user (Rianti and Tuti, 2017).

The officers and drivers for the implementations of open recruitment, capacity building, key performance indicators, and remuneration, for BUMD PT. Jakarta transportation is a priority with a Score of 0,408 . This is because the Transjakarta officers and drivers are the main resources owned by PT. Transportasi Jakarta Transportation to carrying out the implementation and fulfillment of the Transjakarta Minimum Service Standards.

Finally, the business development strategies for investors/private sector with a score of 0.630 . The private sector can be partners in conducting business cooperation and business development with PT. Transportasi Jakarta in organizing Transjakarta. The results of priority from the horizontal analysis of Strategies in Table 7.

Table 7. The results of priority from the horizontal analysis of Strategies

\begin{tabular}{|c|c|c|c|}
\hline Actors & Strategies & Score & Priority \\
\hline \multirow{5}{*}{$\begin{array}{l}\text { Regional/ Local } \\
\text { Government }\end{array}$} & Open recruitment, capacity building, Key Performance Indicators & 0.495 & 1 \\
\hline & Performance-Based Work and Budget & 0.186 & 2 \\
\hline & Business Development & 0.114 & 3 \\
\hline & Assets Handover & 0.107 & 4 \\
\hline & Renewal, Mobilization, and Integrated Control System & 0.098 & 5 \\
\hline \multirow{5}{*}{$\begin{array}{l}\text { PT. Transportasi } \\
\text { Jakarta }\end{array}$} & Open recruitment, capacity building, Key Performance Indicators, remuneration & 0.420 & 1 \\
\hline & Performance-Based Work and Budget & 0.263 & 2 \\
\hline & Renewal, Mobilization, and Integrated Control System & 0.106 & 3 \\
\hline & Assets Handover & 0.106 & 3 \\
\hline & Business Development & 0.106 & 3 \\
\hline \multirow{5}{*}{$\begin{array}{l}\text { Drivers and } \\
\text { officers }\end{array}$} & Open recruitment, capacity building, Key Performance Indicators, remuneration & 0.408 & 1 \\
\hline & Performance-Based Work and Budget & 0.260 & 2 \\
\hline & Renewal, Mobilization, and Integrated Control System & 0.166 & 3 \\
\hline & Assets Handover & 0.083 & 4 \\
\hline & Business Development & 0.083 & 4 \\
\hline \multirow{5}{*}{$\begin{array}{l}\text { Investor/ } \\
\text { Private Sector }\end{array}$} & Business Development & 0.630 & 1 \\
\hline & Renewal, Mobilization, and Integrated Control System & 0.140 & 2 \\
\hline & Performance Base Work and Budget & 0.076 & 3 \\
\hline & Open recruitment, capacity building, Key Performance Indicators & 0.076 & 3 \\
\hline & Assets Handover & 0.076 & 3 \\
\hline
\end{tabular}


The results of synthesis using Expert Choice places Open recruitment, capacity building, Key Performance Indicators, remuneration as priorities. This is in line with the horizontal analysis which shows that the type of basic services that are prioritized for performance improvement is the types of basic services Safety. This mainly related to the indicators of operating procedures and handling of emergencies that are influenced by the variable competencies of resources owned by PT. Transportasi Jakarta. Hardianawati (2012) stated that Transjakarta needs to conduct programs such as service excellence, personal development, and professional ethics. Therefore, the application of open recruitment and capacity building can provide experts and professionals who will contribute to improving the performance of PT. Transportasi Jakarta specifically and Transjakarta services in general. Key performance indicators supported by an increase of the remuneration system will encourage the achievement of service standards along with the level of welfare of the resources owned.

The next strategic priority is renewal, mobilization, and integrated control systems. This strategy needs to be carried out as an effort to fulfill the service standards that related to the indicators of infrastructure and facilities, considering that the units provided by Transjakarta at certain hours cannot accommodate users (Herbowo, 2012). The renewal needs to be done with high specifications and the use of the latest technology. Wibowo et al. (2018) suggested that the link between information needs with public transport systems was the application of Intelligent Transportation Systems (ITS) to use Bus Rapid Transit as a mode of a community movement that had become a solution in solving congestion problems. Darmaningtyas (2014) argues that in achieving optimal implementation of Transjakarta, it needs to be supported by a good control system with the use of modern technology. Therefore, an integrated control system with real-time technology is needed as an instrument of supervision and control over the implementation of Transjakarta.

The acceleration of the handover of the asset is needed so that PT. Transportasi Jakarta can utilize assets to improve services, fulfill service standards, and corporate interests in business development. The strategy for performance base work plan and budget is based to prepare the company's plan not only based on revenue projections but also needs to be supplemented with company performance indicators by each individual. Results of priority strategy of PT. Transportasi Jakarta Performance in Table 8. The results of the vertical analysis regarding the strategy of PT. Transportasi Jakarta performance improvement to fulfill the Minimum Service Standards can be seen in Figure 4.

\section{Managerial Implications}

The Evaluation and strategy to improve the service performance of PT. Transportasi Jakarta has implications for the parties, both within the Regional Owned Enterprises and the Regional Government. For the Board of Directors, it has implications for the implementation of the company's long-term plan vision and mission. For officers and drivers, it has implications for the implementation of Key Performance Indicators in improving the performance and professionalism of services for the public in each Transjakarta corridor. Whereas for the Regional Government as a policymaker and supervisor, this evaluation and strategy will have implications for monitoring and evaluating the performance of business entities on a regular and measurable basis, both from the corporate side and its contribution as one of the transportations programs to reduce the traffic congestion.

Table 8. Results of priority strategy of PT. Transportasi Jakarta Performance

\begin{tabular}{lcc}
\hline Strategies & Score & Priority \\
\hline Open recruitment, capacity building, Key Performance Indicators, remuneration & 0.229 & 1 \\
Renewal, mobilizations and integrated control system & 0.212 & 2 \\
Assets handover & 0.196 & 3 \\
Business development & 0.195 & 4 \\
Performance-based work plan and budget & 0.169 \\
\hline
\end{tabular}




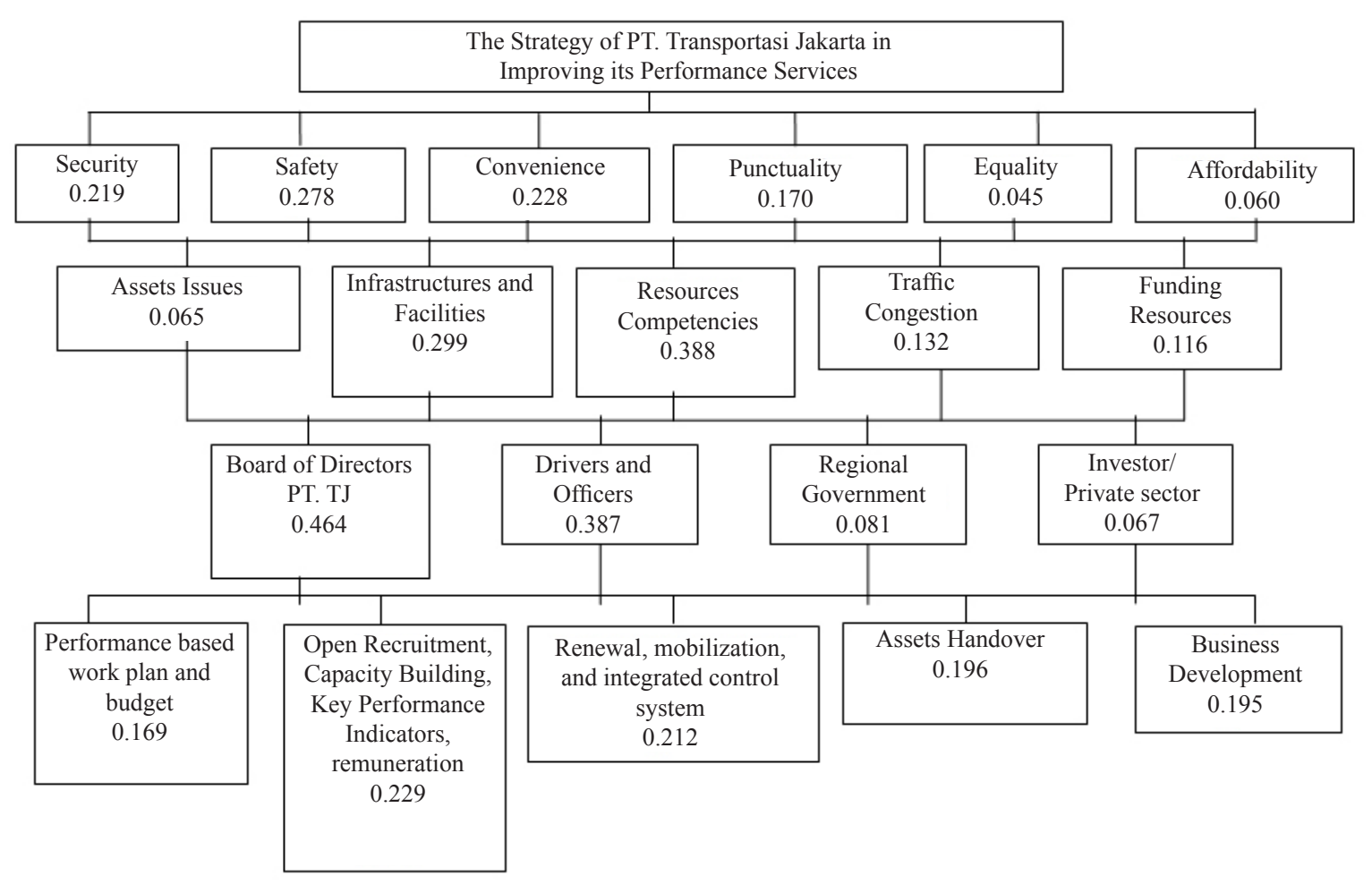

Figure 4. Vertical analysis

\section{CONCLUSIONS AND RECOMMENDATIONS}

\section{Conclusions}

The Performance analysis of PT. Transportasi Jakarta Transportation on the Minimum Service Standards for the 4th Quarter of 2018 shows that in general PT. Transportasi Jakarta Transportation has not yet fulfilled the Minimum Service Standards as regulated in the Governor Regulation Number 33 the Year 2017. However, when compared to the performance in 2017, it has increased. The highest performance of PT. Jakarta Transportation is on the basic types of services in Affordability and Equality, while the lowest is on the basic types of services in Safety. The biggest fines applied to PT. Transportasi Jakarta Transportation is the basic type of services in Punctuality, shows that Transjakarta services still having difficulty providing a punctual public service in the transportations sector.

\section{Recommendations}

The priority of performance improvement PT. Transportasi Jakarta is enhancing its resource competencies. However, the renewal strategy, mobilization, and control system are the core of Transjakarta services to meet the service standards on basic service in Punctuality. The next strategic priority is to gain support from the Government in the asset handover, and business development strategies through investment, business cooperation with transport operators, and optimization of assets for retail and property.

\section{REFERENCES}

Arifin AM, Gemina D, Silaningsih E. 2015. Analisis tingkat kepuasan penumpang pada fasilitas pelayanan bus transjakarta berbasis standar pelayanan minimal (SPM). Jurnal Sosial Humaniora 6(2): 104-121.

Danurekso, P. Salman, Osly, P. Jiwa. 2018. Evaluasi kinerja transjakarta koridor VI A Rute RagunanMonas (via Kuningan). Jurnal Infrastruktur. 4(1): 11-18. https://doi.org/10.35814/infrastruktur. v4i1.713.

Darmaningtyas. 2014. Memberesi Transjakarta Busway. Jakarta: CV. Global Express Media.

[Dishub] Dinas Perhubungan Provinsi DKI Jakarta. 2018. Laporan Evaluasi Survey Capaian SPM Transjakarta Busway. Jakarta: Dishub.

Falatehan A. Faroby. 2016. Analytical Hierarchy Process (AHP) Teknik Pengambilan Keputusan Untuk Pembangunan Daerah. Yogyakarta: Indomedia Pustaka. 
Fitriana, E. Islamiati, Handyani S, Biantara D. 2020. Analisis pemberian public service obligation pada PT. Transportasi Jakarta Periode 20152017. Accounting Cycle Journal 1(1): 110-140.

Gultom E. 2014. Tanggungjawab BLU transjakarta terhadap pihak ketiga dalam hal terjadi kecelakaan Menurut UU No. 22 Tahun 2009 tentang lalu lintas dan angkutan jalan. Jurnal Dinamika Hukum 14(3): 504-517. https://doi. org/10.20884/1.jdh.2014.14.3.314.

Hardianawati. 2012. Analisis Pengaruh Kualitas Pelayanan Jasa Terhadap Kepuasan Masyarakat Pengguna Transjakarta Busway Koridor 2 Pada Pemda DKI Jakarta. Jurnal Dinamika Hukum 1(1): 49-78.

Haryoto E. 2013. Transportasi Pro Rakyat. Jakarta: PT. Gramedia.

Herbowo N. 2012. Studi persepsi pengguna Transjakarta pada koridor II (Pulogadung-Harmoni). Jurnal Perencanaan Wilayah dan Kota 23(1): 37-50. https://doi.org/10.5614/jpwk.2012.23.1.3.
Ismiyati, Firdaus M, Arubusman, D. Artanti. 2016. Manajemen pemeliharaan bus Transjakarta dalam mencapai standar pelayanan minimum. Jurnal Manajemen Transportasi dan Logistik 3(2): 185-203.https://doi.org/10.25292/j.mtl. v3i2.92.

Kamaludin R. 2003. Ekonomi Transportasi Karakteristik, Teori dan Kebijakan. Jakarta: Ghalia Indonesia.

Putra, A. Kusuma, Tangkudung E. 2018. Evaluasi kinerja layanan angkutan pengumpan bus transjakarta rute Lebak Bulus - Senen. Jurnal Transportasi 18(1): 29-38.

Rianti P, Yulfa T, Retnowati WD. 2017. Kualitas pelayanan transjakarta busway di DKI Jakarta. Jurnal Transportasi 15(2): 161-169.

Wibowo, S. Sulaksono, Weningtyas, W, Rahma S. 2018. Kualitas pelayanan sistem informasi pada angkutan umum transjakarta. Jurnal Transportasi 18(1): 67-76. 